p-ISSN : 2541-2345, e-ISSN : 2580-8842

\title{
REDIVASI KELEMBAGAAN OTORITAS PENERIMAAN PAJAK INDONESIA DALAM PEMBAHARUAN SISTEM HUKUM PERPAJAKAN NASIONAL YANG PROGRESIF
}

\author{
Januardo Sulung Partogi Sihombing \\ Fakultas Hukum Universitas Trisakti, Jakarta \\ januardo.sihombing@trisakti.ac.id
}

\begin{abstract}
Abstrak
Tujuan dari penelitian ini adalah untuk menggambarkan urgensi atas tindakan redivasi yang optimal dari Direktorat Jenderal Pajak menjadi Badan Penerimaan Pajak sebagai suatu pembaharuan sistem hukum perpajakan nasional yang progresif. Adapun unsur filosofis yang digunakan dalam penulisan ini adalah kepentingan reinstitusionalisasi dan tujuan negara demi pemberlakuan sistem perpajakan yang progresif. Bagaimana keberadaan Badan Penerimaan Pajak sebagai sebuah backbone negara di pos penerimaan? Bagaimanakah upaya redivasi sistem perpajakan nasional dalam bentuk pelembagaan otorisasi dan norma yang progresif? Penulisan ini menggunakan metode penelitian normatif dan konseptual, menggunakan data sekunder berupa perundang-undangan dan buku-buku yang didukung oleh data primer kemudian dianalisis secara deskriptif dan diolah secara kualitatif. Temuan dari penelitian ini dikaji dari skala penerimaan pajak sebagai backbone di pos penerimaan Negara adalah Indonesia masih dianggap tertinggal jauh, meskipun pembaharuan dan perencanaan perbaikan konsep terus dilakukan oleh Direktorat Jenderal Pajak untuk menjadi suatu badan yang lebih otonom seperti beberapa negara lain. Namun demikian, upaya pembentukan badam ini semakin jauh dari rencana terlebih lagi dengan adanya pembahasan Omnibus Law sektor perpajakan yang justru berpotensi mengurangi penerimaan Negara. Upaya redivasi dalam mewujudkan sistem perpajakan nasional yang progresif dapat diusahakan dengan memberlakukan teori dari Paul Bohannan, yang menjelaskan pentingnya pengaturan pelembagaan kembali dari norma-norma (reinstitutionalization of norms), hal ini sesuai dengan kondisi kelembagaan perpajakan Indonesia yang masih bercampur fungsi budgetair dan regulerendnya sehingga menghambat optimalisasi kinerja.
\end{abstract}

Kata Kunci: redivasi; kelembagaan otoritas; penerimaan pajak; progresif 


\title{
INSTITUTIONAL REFORM ON INDONESIAN TAX REVENUE AUTHORITY IN THE RENEWAL OF PROGRESSIVE NATIONAL TAXATION LEGAL SYSTEM
}

\author{
Januardo Sulung Partogi Sihombing \\ Faculty of Law, Trisakti University, Jakarta \\ januardo.sihombing@trisakti.ac.id
}

\begin{abstract}
The objective of this research is to depict an urgency of an optimal course of institutional reform from Directorate General of Taxes to Tax Revenue Agency as a renewal of progressive national taxation legal system. There shall be some philosophical elements used in this research namely the interests of reinstitutional and the objective of country for the sake of a progressive imposement of taxation system. How is the nature existence of Tax Revenue Agency as the state's backbone in admission posts? Then, how are some reformation measures of national taxation system in a form of authority institutionalization and progressive norms?. This study applies normative and conceptual research methods, work with secondary data which constitute laws and numerous books supported by primary data which then be descriptively analyzed and qualitatively cultivated. Some findings in this research is, if further examined through the scale of tax levy in his accountability as the backbone in the state's admission post that Indonesia considered is a substantially preserved one, though some reformations and plannings of concept advancement have been kept implemented by Directorate General of Taxes to make it a more autonomous agency similar to some other states. Even so, the measure of establishment of this Agency would be much more distant from its plan moreover, the existence of Omnibus Law taxation sector which precisely having a tendency to decrease the state's revenue. The measure of reformation to implement a progressive national taxation system shall be sought with the help from a theory by Paul Bohannan, that describes how important the reinstitutionalization of norms, it is in accordance with the condition of Indonesia's institutional taxation in which its budgetair and regulerend are still functionally combined therefore it then can disrupts its optimal performance.
\end{abstract}

Keywords: reformation; authority institutional, tax revenue, progressive 
p-ISSN : 2541-2345, e-ISSN : 2580-8842

\section{PENDAHULUAN}

\section{A. Latar Belakang}

Pajak bersifat memaksa dan dipungut berdasarkan Undang-Undang merupakan perwujudan kedaulatan rakyat dimana pajak sebagai tulang punggung negara dari segi ekonomi wajib dipergunakan secara adil untuk kesejahteraan. ${ }^{1}$ Hal ini ditegaskan dalam pasal 23A UUD 1945 menyatakan bahwa, "Pajak dan Pungutan Lain yang bersifat memaksa untuk keperluan Negara diatur dengan undang-undang." Black's Law Dictionary mengartikan pajak sebagai sebuah biaya moneter yang dikenakan oleh pemerintah pada orang, badan, transaksi, atau properti untuk menghasilkan pendapatan publik, yang dalam arti luas, mencakup semua istilah pemaksaan pemerintah pada orang, properti, hak istimewa, pekerjaan dan kesenangan orang, dan termasuk bea, pungutan dan cukai. Meskipun pajak sering dianggap secara alami, tidak selalu dibayarkan dengan uang. ${ }^{2}$ Pajak juga dapat dimaknai sebagai iuran rakyat kepada kas negara berdasarkan undang-undang (yang dapat dipaksakan) dengan tiada mendapat jasa timbal (kontraprestasi) yang langsung dapat ditunjukkan dan yang digunakan untuk membayar pengeluaran umum, sebagaimana dikemukakan oleh Rochmat Sumitro. ${ }^{3}$

Dalam beberapa tahun terakhir, Menteri Keuangan RI, Sri Mulyani Indrawati kembali menegaskan tekad Pemerintah sejak tahun 1980-an, yang pada intinya memaknai pajak sebagai tulang punggung bagi vitalitas perekonomian nasional, yang kemudian terealisasi secara yuridis dalam bentuk pengadaan Tax Reform di tahun 1983, 1985', 1991, 1994 $, 1997,2000^{6}$ dan

1 Shidarta, Abdul Rasyid, Ahmad Sofian, Aspek Hukum Ekonomi dan Bisnis (Jakarta: Prenadamedia Group), hal, 224

2 Dalam transkrip aslinya ditulis sebagai: $\operatorname{tax}(n)$. A monetary charge imposed by the government on person, entitles, transaction, or property to yield public revenue; Most broadly, the term embraces all governmental impositions on the person, property, privileges,occupation, and enjoyment of the people, and includes duties, imposts and excises. Although a tax is often thought of as being in nature, it is not necessarily payable on money. Bryan A. Garner, Black's Law Dictionary (T.Tp: Thomson, 1999), hal. 1496, diterjemahkan dalam M. Farouq, Hukum Pajak di Indonesia (Jakarta: Kencana Prenada Media, 2018), hal. 22.

${ }^{3}$ Tony Marsyahrul, Pengantar Perpajakan (Jakarta: Grasindo, 2000), hal 2.

${ }^{4}$ UU hasil tax reform di tahun 1985 adalah UU Nomor 13 Tahun 1985. 
p-ISSN : 2541-2345, e-ISSN : 2580-8842

$2002^{7}$. Hal ini senada dengan pendapat Sarfi Nurmantu ${ }^{8}$ yang menyebutkan bahwa strategi Pemerintah untuk memperbanyak sumur pendapatan negara awalnya bersumber dari latar belakang penurunan harga pasaran minyak dan gas bumi dunia yang berkepanjangan, sehingga sumber daya alam yang penggunaannya relatif sebentar karena terbatasnya pasokan jangka panjang semacam itu, harus mulai ditunjang secara optimal oleh institusi penerimaan negara lain yang lebih praktis, yakni fiscus $^{9}$ pajak dalam hubungannya dengan wajib pajak. Bagi wajib pajak, khususnya para pengusaha, kewajiban dan hak perpajakan merupakan suatu hal yang sulit untuk dihindari. Sebab setiap langkah untuk menjadi pengusaha formal, seperti izin pemerintah daerah dan izin Departemen Perdagangan mempersyaratkan pemenuhan salah satu kewajiban perpajakan, yakni kewajiban mendaftarkan di Kantor Pelayanan Pajak untuk mendapatkan NPWP (Nomor Pokok Wajib Pajak). Untuk itulah, peranan perpajakan masih dan akan selalu dianggap penting untuk mencapai tujuan kesejahteraan sesuai tujuan Negara sebagaimana termaktub dalam Pembukaan Undang-Undang Dasar $1945^{10}$.

Sebagaimana pernah disinggung dalam pidato kenegaraan Presiden RI di hadapan Sidang Paripurna DPR pada tanggal 7 Januari 1989, bahwa "peningkatan penerimaan pajak adalah suatu perjuangan habis-habisan", baik bagi Pemerintah, maupun bagi Wajib Pajak. Pernyataan Presiden kala itu terkait

${ }^{5}$ UU hasil tax reform di tahun 1994 adalah UU Nomor 12 Tahun 1994 tentang Perubahan atas UU Nomor 12 Tahun 1985.

${ }^{6}$ UU hasil tax reform di tahun 2000 adalah UU Nomor 16 Tahun 2000, UU Nomor 17 Tahun 2000, UU Nomor 18 Tahun 2000, UU Nomor 19 Tahun 2000, UU Nomor 20 Tahun 2000 dan UU Nomor 34 Tahun 2000 tentang Perubahan atas UU Nomor 18 Tahun 1997.

${ }^{7}$ UU hasil tax reform di tahun 2002 adalah UU Nomor 14 Tahun 2002 sebagai pengganti UU Nomor 17 Tahun 1997.

${ }^{8}$ Sarfi Nurmantu, Pengantar Perpajakan (Jakarta: Yayasan Obor Indonesia, 2005), hal x.

9 Kata fiscus berasal dari kata Latin "fisc" yang berarti keranjang uang atau pundi-pundi raja yang kemudian mempunyai arti yang lebih luas, yakni bukan saja sebagai tempat menyimpan uang, atau bendahara negara, tetapi juga meliputi petugas dan aparat negara yang bertugas memungut/mengelola keuangan negara, termasuk pajak dan bea-cukai. Dalam pengertiannya secara fiskal, dapat juga diartikan sebagai penerimaan atau pengeluaran uang negara. Ibid, hal. 11 .

${ }^{10}$ Dwi Sulastyawati, Hukum Pajak dan Implementasinya bagi Kesejahteraan Rakyat, SALAM: Jurnal Sosial dan Budaya Syar-i Volume 1 No 1, Fakultas Syariah dan Hukum Universitas Islam Negeri Syarif Hidayatullah, 2014, Jakarta hal. 120. DOI:10.15408/sjsbs.v1i1.1530 
p-ISSN : 2541-2345, e-ISSN : 2580-8842

upaya realisasi penerimaan pajak dapat dikaji melalui tax ratio dalam kurun waktu 17 tahun yakni periode 1990-2007. Tax ratio merupakan suatu tolak ukur sejauh mana Pemerintah melakukan upaya kolektifitas penerimaan pajak atau penyerapan kembali pajak dari total PDB (Produk Domestik Bruto). Merujuk penelitian sebelumnya, selama periode tahun 1990 hingga tahun 2000, maka Tax Ratio Indonesia berada pada kisaran $8 \%$ - $10 \%$. Selanjutya, tax ratio Indonesia mencapai 13,01 \% pada tahun 2000-2007. Namun demikian, angka ini masih lebih rendah dibandingkan dengan indikator cakupan tax ratio versi Bank Dunia yaitu $15 \%$ - $20 \%$ untuk negara berkembang. ${ }^{11}$

Penelitian selanjutnya adalah mengenai kajian penerimaan Wajib Pajak Badan untuk periode 2006 - 2017. Periode 2006-2017 memiliki 2 (dua) catatan monumental dalam histori perpajakan Indonesia yakni program sunset policy di tahun 2008 dan Tax Amnesty (pengampunan Pajak) yang terbagi dalam 3 (tiga) periode yakni Periode 1 dari tanggal diundangkannya UU Pengampunan Pajak hingga 30 September 2016; Periode 2 dari tanggal 1 Oktober 2016 sampai dengan 31 Desember 2016, serta Periode 3 dari tanggal 1 Januari 2017 - 31 Maret 2017. Tujuan dari 2 (dua) program tersebut secara khusus tax amnesty tentunya adalah untuk menjaring potensi penambahan penerimaan pajak yang progresif dan masif untuk mendukung kegiatan pembangunan nasional Negara Kesatuan Republik Indonesia untuk kemakmuran seluruh rakyat Indonesia yang merata dan berkeadilan, hal mana sebagaimana termaktub dalam konsiderans menimbang Undang-Undang Nomor 11 Tahun 2016 tentang Pengampunan Pajak. Dari data penelitian yang diambil dari sampel Kantor Pelayanan Pajak Gambir Empat, maka pengampunan pajak dan tingkat kepatuhan wajib pajak berpengaruh terhadap penerimaan pajak sedangkan pemeriksaan pajak tidak berpengaruh terhadap penerimaan pajak. $^{12}$ Hal yang hendak digaris bawahi

${ }^{11}$ Parmadi, Suatu Deskripsi Tentang Penerimaan Pajak Dalam Negeri Indonesia Periode 1990 - 2007, Jurnal Paradigma Ekonomika Vol. 1, No. 3 April 2011, Fakultas Ekonomi dan Bisnis Jambi, 2011, Jambi, hal 18.

${ }^{12}$ Elvina Desideria dan Ngadiman, Faktor-Faktor Yang Mempengaruhi Penerimaan Pajak Dari Wajib Pajak Badan Tahun 2016-2017, Jurnal Paradigma Akuntansi Volume I No. 2, Fakultas Ekonomi dan Bismis Universitas Tarumanegara, 2019, Jakarta, hal. 362. DOI: http://dx.doi.org/10.24912/jpa.v1i2.5003 
p-ISSN : 2541-2345, e-ISSN : 2580-8842

disini adalah terkait dengan fungsi kelembagaan otoritas pajak dalam menjalankan aspek perpajakan secara budgeter maupun regulerend yang masih memiliki beberapa kendala di lapangan tidak hanya secara internal kelembagaan namun juga secara eksternal ketika berhadapan dengan wajb pajak (pemeriksaan pajak, tata cara pemungutan pajak, edukasi perpajakan, dan kebijakan impelementatif lainya) dalam menggapai target penerimaan negara.

Di era modern sekarang ini, pemungutan pajak yang sudah terintegrasi dalam sistem digital sebagai standar pemungutan pajak yang lebih efisien dan transparan bagi negara, sebenarnya turut bersumber dari Pasal 23 ayat (2) UUD 1945 yang berbunyi; "Segala pajak untuk keperluan negara berdasarkan undang-undang”. Pasal ini juga memiliki keterkaitan kuat dalam hal perwujudan APBN (Anggaran Pendapatan Belanja Negara) yang spesifik dan akuntabel. Jika dikaitkan dengan data realisasi kinerja APBN 2018 (unaudited) yang secara umum dianggap cemerlang, permasalahan tahunan mengenai tidak tercapainya target penerimaan pajak, masih terus berlanjut.

Merujuk data dari Kementerian Keuangan Republik Indonesia, realisasi penerimaan pajak tahun 2018 mencapai Rp 1.315,9 triliun dari target sebesar Rp 1.434 triliun. Dengan demikian, masih ada selisih kurang (shortfall) antara realisasi dan target penerimaan pajak sebesar Rp 108,1 triliun. Lebih lanjut, realiasi penerimaan pajak di tahun 2019 menunjukkan tren menurun yakni sebesar Rp1.545,3 triliun atau sebesar 86,5\% dari target APBN tahun 2019. ${ }^{13}$ Persoalan klasik yang selalu muncul adalah terkait perlunya pembenahan sistem perpajakan yang meliputi aspek regulasi (substance), kebijakan administrasi perpajakan secara kelembagaan (structure), perilaku kepatuhan rakyat selaku wajib pajak (culture).

Pembenahan sistem perpajakan sebagaimana dimaksud di atas seringkali diidentikkan dengan istilah reformasi atau redivasi. Redivasi perlu dilakukan karena kapabilitas organisasi Direktorat Jenderal Pajak dalam melakukan pemungutan pajak semakin menurun seiring berjalannya waktu. Hal ini dapat

${ }^{13}$ Data ini disadur dari situs resmi Kementerian Keuangan Republik Indonesia, https://www.kemenkeu.go.id/publikasi/berita/ini-realisasi-penerimaan-negara-di-penghujung2019/, diakses tanggal 27 Maret 2020. 
p-ISSN : 2541-2345, e-ISSN : 2580-8842

dilihat dari dua indikator, yaitu tren penurunan tax ratio selama sepuluh tahun terakhir dan target penerimaan pajak yang tidak tercapai sejak tahun 2008.

Pembenahan selain berpijak pada isu redivasi organisasi namun juga linier dengan pembaharuan peraturan perundang-undangan yang mencakup revisi Undang-Undang Ketentuan Umum dan Tata Cara Perpajakan (KUP), Pajak Penghasilan (PPh), Pajak Pertambahan Nilai dan Pajak Penjualan Barang Mewah (PPN dan PPnBM), Pajak Bumi dan Bangunan (PBB), serta peraturan pelaksanaannya. Hal ini dilakukan untuk memberi kepastian hukum, menampung dinamika kegiatan perekonomian yang berkembang, baik di pusat maupun daerah dengan mengkorelasikan jumlah penduduk sebagai potensi wajib pajak sehingga dapat meningkatkan pertumbuhan ekonomi yang terkoneksi dengan kebijakan penting lainnya diantaranya perluasan kesempatan kerja. Hal ini selain sebagai tolak ukur keberhasilan pembangunan ekonomi namun juga dapat digunakan sebagai ukuran dalam mencapai kesejahteraan ${ }^{14}$.

Objek penelitian ini pro-kontra mengenai pembaharuan kelembagaan Direktorat Jenderal Pajak menjadi Badan Penerimaan Pajak, sebagai bentuk nyata draf revisi UU Ketentuan Umum dan Tata Cara Perpajakan (KUP) di tahun 2016 yang sampai saat ini masih terbentur kendala. Inti transformasi Direktorat Jenderal Pajak menjadi Badan Penerimaan Pajak adalah seputar keleluasaan dan efektifitas dimana Badan Penerimaan Pajak nantinya akan dibentuk terpisah dengan Kementerian Keuangan dan bertanggung jawab langsung terhadap Presiden. Dengan adanya Badan Penerimaan Pajak tersebut, maka akan ada pemisahan antara fungsi kebijakan dan fungsi administratif perpajakan. Diharapkan upaya Pemerintah dalam mendorong penerimaan pajak dapat berlangsung maksimal. Hal pemisahan fungsi policy dan administrasi itulah yang disinyalir dapat memperluas kepasitas Direktorat Jenderal Pajak dalam menunaikan tugasnya, terutama mengenai tindakan pemeriksaan.

\footnotetext{
${ }^{14}$ Bambang Jatmiko, Ilham Gilar Wicaksono, Analisis Faktor-Faktor yang Mempengaruhi Pendapatan Asli Daerah Kabupaten Banjar Negara (Studi Deskriptif Pada Kabupaten Banjarnegara-Jawa Tengah), Jurnal Akuntansi Trisakti Vol 6 No 2, 2019, Universitas Trisakti, 2019, Jakarta, hal 162.
} 
Berdasarkan hal-hal tersebut diatas, maka penulis bermaksud mengkaji permasalahan terkait dalam sistematika makalah yang berjudul "REDIVASI KELEMBAGAAN OTORITAS PENERIMAAN PAJAK INDONESIA DALAM PEMBAHARUAN SISTEM HUKUM PERPAJAKAN NASIONAL YANG PROGRESIF".

\section{B. Perumusan Masalah}

1. Bagaimana keberadaan Badan Penerimaan Pajak sebagai sebuah backbone negara di pos penerimaan?

2. Bagaimanakah upaya redivasi sistem perpajakan nasional dalam bentuk pelembagaan otorisasi dan norma yang progresif?

\section{Metode Penelitian/Landasan Teoritis}

Penulisan ini menggunakan metode penelitian normatif dan konseptual, menggunakan data sekunder berupa perundang-undangan dan buku-buku yang didukung oleh data primer kemudian dianalisis secara deskriptif dan diolah secara kualitatif. Namun demikian, penulisan ini menggunakan pendekatan socio-legal research. Dasar penggunaan metode pendekatan antara lain dimotori oleh pendapat Dr. Shidarta, S.H., M.Hum., yang mengatakan bahwa "hukum merupakan gejala multifaset”, sehingga kodrat ilmu hukum memang selalu bersinggungan dengan ilmu lain, terutama ilmu sosial. Selain itu, Prof. Dr. Esmi Warassih, S.H., MS., juga mengutip kata-kata Sinzheimer, yang memberikan pesan serupa dengan pendapat Dr. Shidarta, S.H., M.Hum, yakni pendapat bahwa hukum tidaklah bergerak dalam ruang hampa dan berhadapan dengan halhal yang abstrak. Melainkan, ia selalu berada dalam suatu tatanan sosial tertentu dan dalam lingkup manusia-manusia yang hidup. ${ }^{15}$ Heraclitus pernah mengatakan bahwa, dunia ini panta rei, bergerak tanpa henti. Kita menyadari bahwa hukum bukanlah semata-mata rule and logic, tetapi juga behavior. Oleh karena itu, kita seharusnya tidak hanya membaca dan mempelajari teks serta

${ }^{15}$ Esmi Warassih, Pranata Hukum Sebuah Telaah Sosiologis (Semarang: Badan Penerbit Universitas Diponegoro, 2011), hal. xiii. 
p-ISSN : 2541-2345, e-ISSN : 2580-8842

menggunakan logika peraturan saja, melainkan mendalami makna hukum, misalnya makna sosial (social meaning). ${ }^{16}$

\section{PEMBAHASAN}

Jika ditinjau dari dinamika hukum dalam lintas sejarah, penalaahan ilmu secara metodologis umumnya dimulai dari pandangan umum bahwa hukum harus bersifat netral dan objektif dalam kacamata paradigma positivism, yang berangkat dari ajaran Auguste Comte (1798-1857). ${ }^{17}$ Positivisme yang merupakan paradigma warisan dari ilmu alam meyakini bahwa realitas sosial ada dan berjalan sesuai dengan hukum alam, sehingga penelitiannya berpusat pada pengungkapan sebuah realitas yang ada. Seiring berkembangnya masukan keilmuan dan lingkup kemasyarakatan yang berevolusi secara alami, hukum pun senantiasa mengalami perubahan-perubahan konstruktif. Hal ini bersumber dari realitas sosial dimana setiap perubahan sosial terjadi, maka keberadaannya akan mempengaruhi dan membawa perubahan pada hukum dengan sendirinya. Sebab, jika terjadi perubahan sosial, maka kebutuhan masyarakat juga akan berubah secara kuantitatif dan kualitatif. Juga, kebutuhan hukum masyarakat pun dengan itu akan berubah, dan menghendaki perubahan serta tambahan baik kaidah hukum positifnya maupun lembaga hukumnya. ${ }^{18}$

Fakta mengenai hal tersebut akhirnya memayungi pergeseran paradigma positivism menjadi paradigma post positivism, yang fokus utamanya adalah untuk menguji tingkat kebenaran sebuah kepastian dengan melakukan falsifikasi empirik mengenai konsep pemikiran atas keberadaan banyak faktor yang mempengaruhi realita tersebut sebagai suatu hukum yang hidup dalam masyarakat. ${ }^{19}$ Aliran paradigma post positivism sebenarnya berakar dari tiga lingkup kritik, yaitu: 1) pengetahuan mengenai hakikat observasi sebagai unsur utama metode penelitian; 2) adanya hubungan yang kaku antara teori dan bukti

\footnotetext{
${ }^{16}$ Mahfud MD, dkk., Satjipto Rahardjo dan Hukum Progresif: Urgensi dan Kritik (Jakarta: Epistema Institute, 2011), hal. 47.

17 Adji Samekto, Pergeseran Pemikiran Hukum dari Era Yunani Menuju Postmodernisme, (Jakarta: Konstitusi Press, 2015), hal 117.

${ }^{18}$ Bernard Arief Shidarta, Refleksi Tentang Struktur Ilmu Hukum (Bandung: CV Mandar Maju, 2009), hal. 25.

19 Ibid, hal. 183.
} 
p-ISSN : 2541-2345, e-ISSN : 2580-8842

dan 3) tradisi keilmuan yang terus berkembang secara simultan, sehingga sampai pada kesimpulan bahwa observasi tidak akan cukup untuk sampai pada penalaran sosial yang sempurna, sehingga harus ditunjang dengan metode lain (trianggulasi).

Berdasarkan uraian tersebut dan dengan memperhatikan rumusan masalah yang sebelumnya telah diutarakan, maka penelitian tentang redivasi kelembagaan otoritas penerimaan pajak dalam pembaharuan sistem hukum perpajakan nasional menjadi sebuah hasil kajian ilmiah dengan mempertimbangkan keberlakuan paradigma post positivism melalui sebuah substansi, struktur dan budaya hukum spesifik yang dapat membangun suatu sistem penerimaan pajak berbentuk otorisasi kelembagaan demi mencapai kesejahteraan komunal bangsa dari segi ekonomi ${ }^{20}$.

\section{Paradigma}

Paradigma menurut Guba diartikan sebagai seperangkat keyakinan mendasar yang memandu tindakan-tindakan orang, baik tindakan sehari-hari maupun tindakan ilmiah. ${ }^{21}$ Menurut Ritzer, paradigma adalah pandangan yang mendasar dari ilmuwan tentang apa yang menjadi pokok persoalan yang mestinya dipelajari oleh suatu cabang ilmu pengetahuan (discipline). Paradigma membantu merumuskan tentang: 1) apa yang harus dipelajari; 2) persoalanpersoalan apa yang mesti dijawab; 3) bagaimana seharusnya menjawabnya serta 4) aturan-aturan apa yang harus diikuti dalam rangka menjawab persoalan tersebut.

Setiap paradigma terbangun dari tiga pertanyaan mengenai aspek ontologis, epitimologis dan metodologis. Rumusan spesifik atas pertanyaan dimaksud akan menentukan suatu paradigma tertentu untuk memberikan jawaban, yang mana satu jawaban berkaitan erat dengan dua pertanyaan lainnya. Ketiga pertanyaan tersebut terbentuk dari skema pemikiran sebagai berikut: ${ }^{22}$

\footnotetext{
${ }^{20}$ Nuning Sumaryani, Pengaruh Penerimaan Pajak Terhadap Pertumbuhan Ekonomi di Indonesia, Surakarta, Https://dfs.semanticscholar.org, Diakses pada Tanggal 3 Februari 2020

${ }^{21}$ Agus Salim, Teori dan Paradigma Penelitian Sosial (Pemikiran Norman K. Denzin dan Egon Guba, dan penerapannya) (Yogyakarta: PT Tiara Wacana: 2001), hal. 33.

${ }^{22}$ N.K Denzin dan Y.S Lincoln (Ed.), Handbook of Qualitative Research, Cet. 1, Terjemahan Dariyanto dkk. (Yogyakarta: Pustaka Pelajar, 2009), hal.133.
} 
p-ISSN : 2541-2345, e-ISSN : 2580-8842

1. Pertanyaan Ontologis. Apakah bentuk dan sifat realitas dan apakah yang ada disana yang dapat diketahui tentangnya?

2. Pertanyaan Epistemologis. Apakah hubungan antara yang mengetahui dengan sesuatu yang dapat diketahui?

3. Pertanyaan Metodologis. Bagaimanakah cara peneliti untuk menemukan jawaban apa ia percaya dapat diketahui?

Dari sumber tiga pertanyaan dasar tersebut, Guba dan Lincoln membagi paradigma menjadi empat paradigma utama, yaitu: positivism, postpositivism, critical theory dan constructivism. Sementara Guba dan Denzin membagi pengelompokan paradigma penelitian menjadi lima, yaitu: positivism atau naturalism, post positivism, critical theory, constructivism dan participatory. Penelitian ini berpihak pada paradigma post positivism, yang dapat dirumuskan sebagai berikut:

\section{Aspek Ontologis}

Fungsi penerimaan negara dari sumur perpajakan nasional diotorisasi oleh Direktorat Jenderal Pajak, yang bertanggung jawab kepada Menteri Keuangan. Ultimasi fungsi kebijakan dan administratif perpajakan yang dibebankan kepada Direktorat Jenderal Pajak merupakan realisasi nilai kebijakan dalam bentuk lembaga resmi Pemerintah dan akumulasi kepercayaan moril masyarakat dalam pemenuhan kewajiban pajak. Secara nyata, hal ini merupakan upaya untuk menambah pendapatan negaradalam menunjang kesejahteraan rakyat dan pembangunan nasional. ${ }^{23}$

2. Aspek Epistemologis

Karena sifat epistemologis paradigma post positivism yang interaktif dan netral, maka objektivitasi peneliti hanya dapat diperkirakan dan bergantung pada suatu tradisi / komunitas yang kritis. Dalam hal ini, Direktorat Jenderal Pajak dapat dikaji pengembanan tugasnya, serta disesuaikan dengan praktik empiris dalam melaksanakan amanat negara dari sisi ekonomi. Penelitian ini akan mengkaji temuan-temuan reflektif yang menjadi cerminan

${ }^{23}$ Leonard Makalalag, Pengenaan Pajak Penghasilan Terhadap Pengusaha Dalam Transaksi Perdagangan Online (E-Commerce), Legal Opinion Jurnal Ilmu Hukum Voulume 4 Edisi 1, Universitas Tadulako, 2016, Kendari, hal 2. 
p-ISSN : 2541-2345, e-ISSN : 2580-8842

penyelenggaraan administasi perpajakan yang efisien dan sesuai dengan nilainilai Pancasila dan UUD 1945.

3. Aspek Metodologis

Penelitian ini akan membahas tentang tindakan komparasi terhadap negaranegara yang memang telah menetapkan suatu otorisasi penerimaan pajak yang mandiri, serta langsung bertanggung jawab kepada Presiden dan bukan kepada Menteri Keuangan, dan selanjutnya akan bermuara pada solusi yang komprehensif bagi pengembanan hukum perpajakan yang progresif.

\section{Badan Penerimaan Pajak sebagai sebuah backbone Negara di Pos Penerimaan}

Gagasan mengenai pembentukan Badan Penerimaan Pajak merupakan salah satu program Presiden Joko Widodo yang tercantum dalam Nawacita untuk membangun kemandirian dan kedaulatan bangsa. Karenanya, kini menjadi tugas Tim Reformasi Perpajakan untuk mendesain bentuk Badan Penerimaan Pajak seperti apa, stuktur kelembagaan organisasinya, SDM-nya, kompleksitas tugas serta ruang lingkup seluruh pekerjaannya dari Sabang sampai Merauke. Semua ini penting direncanakan sejak awal agar tugas dan fungsi Badan Penerimaan Pajak dapat berjalan efektif. Payung hukum pembentukan Badan Penerimaan Pajak pun telah tercakup dalam draf revisi Undang-Undang Ketentuan Umum dan Tata Cara Perpajakan yang isinya mengamanatkan pembentukan Badan Penerimaan Pajak pada tanggal 1 Januari 2018, yang hingga saat ini meleset dan belum terealisasi.

Meski belum terbentuk secara mandiri, sejumlah kalangan telah terangterangan mendukung pembentukan lembaga ini. Mereka menilai bahwa pembentukan Badan Penerimaan Pajak akan memudahkan Pemerintah dalam mengatur dan mengelola penerimaan negara secara produktif. Badan Penerimaan Pajak akan menjadi backbone negara di pos penerimaan. Karenanya, Badan Penerimaan Pajak harus diberi kewenangan yang besar dan memiliki seluruh komponen yang dibutuhkan untuk mencapai target penerimaan pajak. Hal ini masih saja bertitiktolak dari satu akar penyakit yang sama: realisasi penerimaan pajak yang tidak sesuai target. Bahkan pada saat draf revisi 
p-ISSN : 2541-2345, e-ISSN : 2580-8842

UU Ketentuan Umum dan Tata Cara Perpajakan dibahas di akhir tahun $2016^{24}$, realisasi penerimaan pajak tercatat $\mathrm{Rp} 1.032,2$ triliun atau ekuivalen dengan 76,17\% dari target APBN-P 2016 yang ditargetkan sebesar Rp 1.355,2 triliun. Walaupun ada peningkatan kapasitas penerimaan Negara pasca program Tax Amnesty, permasalahan klasik terkait aspek regulasi (substance), kebijakan administrasi perpajakan secara kelembagaan (structure), perilaku kepatuhan rakyat selaku wajib pajak (culture) masih tetap sama merujuk fakta 3 (tiga) tahun terakhir. Bahkan, Tax Amnesty yang dipandang berhasil sekalipun menyimpan beberapa permasalahan yang cukup fundamental diantaranya; (1) menimbulkan rasa ketidakadilan khususnya bagi wajib pajak yang patuh, (2) dapat menimbulkan sikap ketidakpatuhan Wajib Pajak untuk tidak membayar pajak dulu karena Wajib Pajak berharap ada Tax Amnesty di masa yang akan datang. ${ }^{25}$

Fakta 3 (tiga) tahun terakhir pun menunjukkan bahwa target pendirian Badan Penerimaan Pajak di awal tahun 2018 dan 2019 sebagaimana terurai di atas belum tercapai dimana Pemerintah tampaknya masih fokus melakukan upaya mengejar potensi pajak dari program amnesti pajak maupun penerimaan rutin. Bahkan, keadaan yang terjadi di akhir 2019 hingga awal 2020 adalah pergeseran dinamika kepentingan yang sifatnya substantif yakni pembahasan RUU Ketentuan dan Fasilitas Perpajakan untuk Penguatan Perekonomian atau dikenal dengan nama Omnibus Law sektor perpajakan. Omnibus Law sektor perpajakan menghadapi kembali pro kontra di tataran substansi termasuk adanya pernyataan dari Dirjen Pajak bahwa pemberlakuan aturan ini berpengaruh terhadap potensi penyusutan penerimaan Negara sebesar Rp 80 trilliun. ${ }^{26}$

24 Di tahun yang sama ini, juga telah dibentuk Tim Reformasi Perpajakan melalui Keputusan Menteri Keuangan 885/KMK.03/2016 tentang Pembentukan Tim Reformasi Perpajakan, sebagai langkah awal merealisasikan rencana pembentukan Badan Penerimaan Pajak.

25 Budi Ispriyarso, Keberhasilan Kebijakan Pengampunan Pajak (Tax Amnesty) di Indonesia, Adminitrative Law \& Governance Journal Volume 2 Issue 1, March 2019, Fakultas Hukum Universitas Diponegoro, 2019, Semarang, hal. 55-56.

26 Pernyataan ini disampaikan oleh Suryo Utomo, Direktur Jenderal Pajak dalam acara media briefing di kantor Ditjen Pajak pada tanggal 11 Februari 2020 dalam rangka pembahasan Omnibus Law perpajakan, diunduh dari https://investor.id/business/omnibus-law-bisa-geruspenerimaan-rp-80-t-pemerintah-siapkan-mitigasi tanggal 25 Maret 2020 pukul 10.30 WIB. 
p-ISSN : 2541-2345, e-ISSN : 2580-8842

Target penerimaan Negara harus menyentuh aspek fundamental yakni aspek kelembagaan yang memberikan kewenangan serta efektifitas kinerja yang lebih luas, Pembentukan Badan Penerimaan Pajak dapat membenahi penerimaan pajak yang stagnan ketika dijalankan Direktorat Jenderal Pajak. Meskipun kini Direktorat Jenderal Pajak memiliki tugas besar mengejar target penerimaan pajak yang ditetapkan dalam APBN, namun kelembagaannya hanya diatur berdasarkan Peraturan Menteri Keuangan sebagai turunan Peraturan Presiden tentang Struktur Organisasi Kementerian. Masalahnya terletak pada inkonsistensi. Setiap berganti kabinet, maka berganti pula regulasinya.

Kemudian, Direktorat Jenderal Pajak tidak memiliki keuangan dalam mengatur SDM, organisasi dan anggaran sendiri. Direktorat Jenderal Pajak sebagai otoritas pajak masih dikelompokkan sebagai single directorate in Ministry of Finance. Fakta ini jelas berbeda dengan negara-negara lain di Asia Tenggara seperti Singapura, Filipina dan Malaysia yang mendelegasikan kewenangan SDM, anggaran dan organisasi ke unit otoritas pajaknya atau Semi Autonomous Revenue Authority (SARA). Singapura telah membentuk badan terpisah bagi penerimaan negara sejak tahun 1993 silam. Sedangkan Malaysia telah melakukannya sejak tahun 1992. Sejak itu pula, penerimaan pajak mereka naik signifikan. Belajar dari dua negara tetangga itu, Indonesia sudah saatnya memberikan otonomi kepada otoritas pajak melalui redivasi perpajakan di sektor penerimaan negara. Otonomi tersebut dapat menjadikan otoritas pajak lebih independen secara organisasi dan dapat mengurangi tekanan politik kepada Kemenkeu.

Redivasi perpajakan tidak akan bermakna apabila pembentukan Badan Penerimaan Pajak tidak direalisasikan secepatnya. Selama tidak ada Badan Penerimaan Pajak, maka akan selalu muncul konflik kepentingan antara Direktorat Jenderal Pajak sebagai direktorat yang bertugas mengumpulkan penerimaan pajak dan Direktorat Jenderal Anggaran sebagai direktorat yang mengelola dan mengatur penggunaan anggaran negara. Tentu kedepannya diharapkan agar terbentuknya Badan Penerimaan Pajak dapat menyelesaikan permasalahan yang dihadapi negara dalam mengumpulkan pajak. Kebutuhan 
p-ISSN : 2541-2345, e-ISSN : 2580-8842

membentuk Badan Penerimaan Pajak semakin mendesak seiring terjadinya kekurangan (shortage) penerimaan negara dari pajak tahun ini. Karena berada di bawah kendali Presiden langsung, Badan Penerimaan Pajak akan lebih efektif menjalankan fungsi, tugas dan wewenangnya, berbeda dengan keberadaan Direktorat Jenderal Pajak yang selama ini selalu bertindak tidak leluasa menggali pendapatan pajak secara optimal.

Hal ini bukan berarti bahwa Pemerintah harus secara buta membentuk Badan Penerimaan Pajak tanpa memenuhi nilai-nilai vital perekonomian negeri dan pertimbangan mengenai persyaratan pokok good governance system, seperti penjaminan transparansi, mekanisme pengawasan serta integritas aparat yang bertugas, sebagai cara pencegahan adanya penyalahgunaan kewenangan Badan Penerimaan Pajak oleh oknum yang tidak bertanggung jawab.

\section{Redivasi Sistem Perpajakan Nasional sebagai bentuk Pelembagaan Otorisasi dan Norma yang Progresif}

Dalam mendukung sebuah tindakan redivasi yang optimal, maka diperlukan sebuah tinjauan hukum disamping pemberlakukan tinjauan kebijakan. Lebih daripada pengaturan seputar otorisasi wewenang dalam kelembagaan perpajakan, maka pengaturan pelembagaan kembali dari normanorma (reinstitutionalization of norms) ${ }^{27}$ justru tak kalah esensial. Penggagas hal ini, Paul Bohannan, menegaskan bahwa cara menyelesaikan perselisihan yang timbul dalam sebuah institusi dengan tugas kemasyarakatan lainnya (dalam hal ini tugas institusi perpajakan dalam menghimpun dana), harus mencakup dua jenis aturan, yaitu penetapan kembali aturan-aturan kelembagaan dan penetapan tatanan aktivitas dari kelembagaan hukum itu sendiri secara sejalan.

Pendapat Bohannan sangat penting untuk diperhatikan karena dengan pernyataannya tersebut, ia berpendapat bahwa sifat yang penting dari gejala hukum adalah fakta bahwa aturan dari kelembagaan tersebut mengatur hampir seluruh perikelakuan sosial dalam masyarakat (terkait dengan tingkat kepatuhan dan kepercayaan wajib pajak terhadap fiscus). Menindaklanjuti pendapat dari Prof. Dr. Haula Rosdiana, M.Si., dalam salah satu wawancaranya dengan

${ }^{27}$ Soerjono Soekanto, Pokok-pokok Sosiologi Hukum (Jakarta: Rajawali Pers, 2006), hal. 73. 
p-ISSN : 2541-2345, e-ISSN : 2580-8842

Redaksi Ortax, kelembagaan dan otoritas perpajakan tidak hanya difokuskan untuk bertindak praktis dalam melakukan pungutan wajib, namun juga sebagai penjalanan nilai “demi kesejahteraan”, yaitu kesejahteraan yang berkeadilan sesuai cita-cita bangsa menurut UUD 1945 dari segi ekonomi nasional sebagai hasil pengembanan political will negara yang meluas.

Selain mengaplikasikan teori Bohannan dalam disfungsi kelembagaan pajak kini, "tujuan progresivitas" harus ditempuh dengan melakukan pengutamaan kepentingan sosial masyarakat sebagai akar rumput. Dalam menghindari kondisi dimana masyarakat merasa teralienasi oleh hukum yang dijalankan aparat (dalam hal ini hukum dalam mengultimasikan kewajiban Wajib Pajak untuk melaksanakan kewajiban perpajakannya), pendapat Prof. Satjipto Rahardjo tentu merupakan payung berfilsafat yang paling tepat. Dengan tataran studi hukum kritis yang disempurnakan dengan misi emansipatoris, formalisme hukum tidak dianggap sebagai satu-satunya gerbang legitim untuk menerangi cara pandang dan bertindak. Unsur ini disebut oleh beliau sebagai optik yang memihak kepentingan sosial (sozialen interessen). ${ }^{28}$

Prof. Soetandyo Wignjosoebroto turut ambil bagian dalam memberikan pandangan sosial terhadap penulis, terutama dalam pemikiran beliau yang diramu dalam judul publikasi "Pancasila: Sebagai Pilar Pendidikan Hukum dan Kewarganegaraan”, melalui narasi Tanius Sebastian. Untuk pengembangan ilmu sosial yang progresif, terutama ilmu hukum yang berkeadilan dan taat nilai, Pancasila tetap harus dijadikan acuan utama. Beliau memberikan pandangan bahwa pancasila itu ada bagaikan matahari. Letaknya nan jauh di atas angkasa sana, dan tak sama sekali membumi. Namun meski begitu, ia tetap bertaraf selaku energi. Jika benar-benar dicermati, dalam suasana kultural yang dibalut dengan berbagai kenyataan sosio-politis di masyarakat, hanya energi semacam itu yang dapat menggerakkan kehidupan.

Secara nyata, maka arah pembentukkan Badan Penerimaan Pajak tentu harus berpijak pada suatu kerangka asas penyelenggaraan pemerintahan yang baik untuk menghindari tindakan sewenang-wenang pemerintah selaku

\footnotetext{
${ }^{28}$ Mahmud MD, Ibid., hal. 84.
} 
p-ISSN : 2541-2345, e-ISSN : 2580-8842

penguasa. Selain itu, pembentukkan kelembagaan baru harus sejalan dengan arah pembangunan ekonomi bangsa dimana pajak adalah pilar penerimaan yang sangat vital bagi pembangunan. Dengan demikian, kebijakan ini seyogyanya juga bertujuan untuk mencapai suatu iklim perpajakan yang adil dan kondusif serta memberikan kepastian hukum ${ }^{29}$. Modernisasi perpajakan yang dilakukan dalam bentuk redivasi kelembagaan oleh Pemerintah tentunya tidak hanya untuk mengejar optimalisasi pemungutan pajak (budgeter) semata. Hal yang patut dijadikan pondasi adalah adanya perubahan paradigma perpajakan (change of tax paradigm) melalui suatu redivasi kelembagaan, revitalisasi regulasi, pelayanan wajib pajak, kepastian hukum, serta penciptaan iklim dunia usaha yang business friendy.

\section{PENUTUP}

Indonesia masih dianggap tertinggal jauh, meskipun pembaharuan dan perencanaan perbaikan konsep terus dilakukan oleh Direktorat Jenderal Pajak untuk menjadi suatu badan yang lebih otonom seperti beberapa negara lain. Namun demikian, upaya pembentukan Badan ini semakin jauh dari rencana terlebih lagi dengan adanya pembahasan Omnibus Law sektor perpajakan yang justru berpotensi mengurangi penerimaan Negara. Upaya redivasi dalam mewujudkan sistem perpajakan nasional yang progresif dapat diusahakan dengan memberlakukan teori dari Paul Bohannan, yang menjelaskan pentingnya pengaturan pelembagaan kembali dari norma-norma (reinstitutionalization of norms), hal ini sesuai dengan kondisi kelembagaan perpajakan Indonesia yang masih bercampur fungsi budgetair dan regulerendnya sehingga menghambat optimalisasi kinerja. Sifat emansipatoris dari teori Bohannan tersebut yang sejalan dengan pengembanan hukum progresif menurut Prof. Satjipto Rahardjo, dapat pula diperluas keberadaannya dengan melakukan studi komparatif dan wawancara terhadap negara-negara yang telah memiliki lembaga penerimaan pajak secara mandiri (langsung di bawah Presiden), yang dikenal juga dengan negara-negara yang telah

${ }^{29}$ Amin Purnawan, Rekonstruksi Sistem Pemungutan Pajak Penghasilan (PPh) Badan Berbasis Nilai Keadilan, Jurnal Dinamika Hukum, Vol. 11, Edisi Khusus Februari 2011, Fakultas Hukum, Universitas Jenderal Soedirman, 2011, Purwokerto, hal. 41. 
Redivasi Kelembagaan Otoritas Penerimaan Pajak Indonesia Dalam Pembaharuan Sistem Hukum

p-ISSN : 2541-2345, e-ISSN : 2580-8842

mengaplikasikan sistem Semi Autonomous Revenue Authority atau yang biasa disingkat dengan istilah SARA (mengingat Indonesia kini masih berada dalam kondisi non-SARA). Indonesia seharusnya fokus kepada fundamental permasalahan yang ada dalam hal pungutan pajak sebagai backbone di pos penerimaan Negara melalui pemberdayaan kelembagaan melalui pembentukan Badan Penerimaan Pajak secara mandiri.

\section{Buku}

\section{DAFTAR PUSTAKA}

Farouq, M. 2018. Hukum Pajak di Indonesia Jakarta: Kencana Prenada Media.

Marsyahrul, Tony. 2000. Pengantar Perpajakan Jakarta: Grasindo.

MD, Mahmud, dkk. 2011. Satjipto Rahardjo dan Hukum Progresif: Urgensi dan Kritik. Jakarta: Epistema Institute.

Nurmantu, Sarfi. 2005. Pengantar Perpajakan. Jakarta: Yayasan Obor Indonesia.

Samekto, Adji. 2015. Pergeseran Pemikiran Hukum dari Era Yunani Menuju Postmodernisme. Jakarta: Konstitusi Press.

Shidarta, Bernard Arief. 2009. Refleksi tentang Struktur Ilmu Hukum. Bandung: CV Mandar Maju.

Shidarta, Abdul Rasyid dan Ahmad Sofian, 2018. Aspek Hukum Ekonomi dan Bisnis. Jakarta: Prenadamedia Group.

Soekanto, Soerjono. 2006. Pokok-pokok Sosiologi Hukum. Jakarta: Rajawali Pers.

Warassih, Esmi. 2011. Pranata Hukum Sebuah Telaah Sosiologis. Semarang: Badan Penerbit Universitas Diponegoro.

\section{Jurnal}

Amin Purnawan, Rekonstruksi Sistem Pemungutan Pajak Penghasilan (PPh) Badan Berbasis Nilai Keadilan, Jurnal Dinamika Hukum, Vol. 11, Edisi Khusus Februari 2011, Fakultas Hukum, Universitas Jenderal Soedirman, Purwokerto, http://dx.doi.org/10.20884/1.jdh.2011.11.Edsus.260

Bambang Jatmiko, Ilham Gilar Wicaksono, Analisis Faktor-Faktor yang Mempengaruhi Pendapatan Asli Daerah Kabupaten Banjar Negara (Studi Deskriptif Pada Kabupaten Banjarnegara-Jawa Tengah), Jurnal Akuntansi Trisakti 6 (2), 2019, http://dx.doi.org/10.25105/jat.v6i2.5580

Budi Ispriyarso, Keberhasilan Kebijakan Pengampunan Pajak Pajak (Tax Amnesty) di Indonesia, Adminitrative Law \& Governance Journal Volume 2 Issue 1, March 2019, https://doi.org/10.14710/alj.v2i1.47 - 59 
p-ISSN : 2541-2345, e-ISSN : 2580-8842

Dwi Sulastyawati, Hukum Pajak dan Implementasinya bagi Kesejahteraan Rakyat, SALAM: Jurnal Sosial dan Budaya Syar-i Volume 1 No 1, Fakultas Syariah dan Hukum Universitas Islam Negeri Syarif Hidayatullah, 2014, Jakarta DOI: $\underline{10.15408 / \text { sjsbs.v1i1.1530 }}$

Elvina Desideria dan Ngadiman, Faktor-Faktor Yang Mempengaruhi Penerimaan Pajak Dari Wajib Pajak Badan Tahun 2016-2017, Jurnal Paradigma Akuntansi Volume I No. 2, Fakultas Ekonomi dan Bismis Universitas Tarumanegara, 2019, Jakarta. DOI: http://dx.doi.org/10.24912/jpa.v1i2.5003

Leonard Makalalag, Pengenaan Pajak Penghasilan Terhadap Pengusaha Dalam Transaksi Perdagangan Online (E-Commerce), Legal Opinion Jurnal Ilmu Hukum Voulume 4 Edisi 1, Universitas Tadulako, 2016, Kendari,

Parmadi, Suatu Deskripsi Tentang Penerimaan Pajak Dalam Negeri Indonesia Periode 1990 - 2007, Jurnal Paradigma Ekonomika Vol. 1, No. 3 April 2011, Fakultas Ekonomi dan Bisnis Jambi, 2011, Jambi.

\section{Undang-Undang}

Undang-Undang Nomor 13 Tahun 1985 Tentang Bea Materai

Undang-Undang Nomor 12 Tahun 1994 Tentang Perubahan atas UU Nomor 12 Tahun 1985 Tentang Pajak Bumi dan Bangunan.

Undang-Undang Nomor 16 Tahun 2000 Tentang Perubahan Kedua atas Undang-

Undang Nomor 6 Tahun 1983 Tentang Ketentuan Umum dan Tata Cara

Perpajakan

Undang-Undang Nomor 14 Tahun 2002 Tentang Pengadilan Pajak

Undang-Undang Nomor 28 Tahun 2007 Tentang Perubahan Ketiga atas Undang-

Undang No 6 Tentang Ketentuan Umum dan Tata Cara Perpajakan

Undang-Undang Nomor 36 Tahun 2008 Tentang Pajak Penghasilan

Undang-Undang Nomor 28 Tahun 2009 Tentang Pajak Daerah dan Retribusi Daerah

\section{Internet}

https://investor.id/business/omnibus-law-bisa-gerus-penerimaan-rp-80-t-pemerintahsiapkan-mitigas

https://www.kemenkeu.go.id/publikasi/berita/ini-realisasi-penerimaan-negara-dipenghujung-2019

https://dfs.semanticscholar.org, 